\title{
Some characteristics of very heavy rainfall over Orissa during summer monsoon season
}

\author{
M Mohapatra ${ }^{1}$ and U C Mohantr ${ }^{2 *}$ \\ ${ }^{1}$ India Meteorological Department, Guwahati 781 015, India. \\ ${ }^{2}$ Centre for Atmospheric Sciences, Indian Institute of Technology, Delhi Hauz Khas, New Delhi 110 016, India. \\ *e-mail:mohanty@cas.iitd.ernet.in
}

Orissa is one of the most flood prone states of India. The floods in Orissa mostly occur during monsoon season due to very heavy rainfall caused by synoptic scale monsoon disturbances. Hence a study is undertaken to find out the characteristic features of very heavy rainfall ( 24 hours rainfall $\geq 125 \mathrm{~mm}$ ) over Orissa during summer monsoon season (June-September) by analysing 20 years (1980-1999) daily rainfall data of different stations in Orissa. The principal objective of this study is to find out the role of synoptic scale monsoon disturbances in spatial and temporal variability of very heavy rainfall over Orissa.

Most of the very heavy rainfall events occur in July and August. The region, extending from central part of coastal Orissa in the southeast towards Sambalpur district in the northwest, experiences higher frequency and higher intensity of very heavy rainfall with less interannual variability. It is due to the fact that most of the causative synoptic disturbances like low pressure systems (LPS) develop over northwest (NW) Bay of Bengal with minimum interannual variation and the monsoon trough extends in west-northwesterly direction from the centre of the system. The very heavy rainfall occurs more frequently with less interannual variability on the western side of Eastern Ghat during all the months and the season except September. It occurs more frequently with less interannual variability on the eastern side of Eastern Ghat during September. The NW Bay followed by Gangetic West Bengal/Orissa is the most favourable region of LPS to cause very heavy rainfall over different parts of Orissa except eastern side of Eastern Ghat. The NW Bay and west central (WC) Bay are equally favourable regions of LPS to cause very heavy rainfall over eastern side of Eastern Ghat. The frequency of very heavy rainfall does not show any significant trend in recent years over Orissa except some places in northeast Orissa which exhibit significant rising trend in all the monsoon months and the season as a whole.

\section{Introduction}

The monsoon rainfall over India is characterised by heavy to very heavy rainfall events leading to floods over different regions. These heavy to very heavy rainfall events are caused by the interaction of basic monsoon flow with the orography and the synoptic disturbances developing over Indian region. Dhar and Nandargi (1993, 1993a) have found that severe rainstorms over different parts of India do not occur uniformly. They have found that during the period from 1880 to 1990, 8 rainstorms have occurred over Orissa out of total 97 affecting the whole country. The number of rain storms has been maximum over undivided Madhya Pradesh (15) followed by Maharastra (12), Gujarat and Karnataka (9 each). All the rain storms, which have occurred over Orissa, have taken place during monsoon season only. Also the break up of meteorological disturbances causing

Keywords. Very heavy rainfall; low pressure system; orography; monsoon; Orissa. 
the rainstorms indicates that most of the rainstorms are caused due to low pressure systems (LPS) which include low, depression, deep depression and cyclonic storm.

Orography plays a significant role on intensity and distribution of rainfall. Smith (1979) has suggested the three independent mechanisms of orographic rainfall, viz. (i) large scale slope precipitation due to orographically forced vertical motion or convection triggered by smooth orographic ascent bringing the air to saturation resulting in precipitation, (ii) rainfall from the pre-existing clouds is partially evaporated before hitting low ground and (iii) the rainfall due to orographic control of the formation of cumulonimbus clouds in a conditionally unstable air mass. Banerjee (1929) has observed the effect of orography on the monsoon flow and distribution of rainfall in India. Sarkar $(1966,1967)$ has made extensive studies of the rainfall due to dynamical lifting of neutrally stratified and moist air in the westerlies over the crest of Western Ghat. Krishnamurti et al (1976) have found that the low level monsoon circulations are quite sensitive to the mountain barriers around Western Ghat region. Browning (1980) has observed that rainfall over hills of small or medium size can be very large if there is a strong and nearly saturated low level flow. Kasahara (1980) has found that the distribution of mountain has a substantial effect on the large scale monsoon circulation in the region. Rao and Rao (1993) have studied the influence of cyclonic disturbances from sea on rainfall over Eastern Ghat in Andhra Pradesh and found that during southwest monsoon months of June to August, the southern part of Eastern Ghat does not receive heavy rain due to depression/storm. There has been many studies on heavy rainfall over different regions (Dubey and Balakrishnan 1992, Desai et al 1996; Chand and Gupta 1991; Ganesan et al 2001). Most of the above are case studies. However, Dubey and Balakrishnan (1992) have studied the frequency distribution of very heavy rainfall days over different stations in Madhya Pradesh and the causative systems of these very heavy rainfall events. Rakhecha and Pisharoty (1996) have studied point and spatial distribution of heavy rainfall over India during monsoon season.

Orissa state, a meteorological sub-division of India, lies on the east coast of India, adjacent to north Bay of Bengal and close to the south of the eastern end of monsoon trough in Indian region. Hence rainfall in general and very heavy rainfall in particular over Orissa is predominantly determined by the interaction of basic monsoon flow with the orography in Orissa due to Eastern Ghat and other mountain ranges and synoptic disturbances like LPS developing over the Bay of Bengal along the monsoon trough. However, the rainfall over Orissa varies with reference to the intensity, movement and region of location of LPS. Hence very heavy rainfall activity over Orissa is highly complex in nature. Dhar and Mhaiskar (1973) have studied point and spatial distribution of rainfall over coastal Orissa in association with depression/storm and found the occurrence of intense rainfall to the south of the monsoon trough extending from the centre of depression/storm.

Here an attempt is made to find out some characteristics of daily 24 hours accumulated very heavy rainfall (rainfall greater than or equal to $125 \mathrm{~mm}$ ) recorded at 0830 IST over different stations in Orissa and their causative synoptic systems. Also the role of orography on very heavy rainfall events in Orissa has been analysed. The principal objective of this study is to find out the role of synoptic scale monsoon disturbances on spatial and temporal variability of frequency and intensity of very heavy rainfall over Orissa. This study will help in further analysis and development of appropriate models for prediction of very heavy rainfall events over Orissa.

\section{Data and methodology}

Orissa state, a meteorological sub-division of India, lies on the east coast of India, adjacent to north Bay of Bengal and close to the south of the normal position of monsoon trough (figure 1a). Figure 1(a) indicates the geographical location of Orissa along with the surface isobaric pattern, mean wind at $0.9 \mathrm{~km}$ above mean sea level and normal position of monsoon trough at mean sea level in representative monsoon month of July. This figure indicates that the maximum rainfall occurs to the south of the monsoon trough and the line of maximum rainfall passes through Orissa. It also indicates that the basic monsoon flow over Orissa is westerly. With the synoptic disturbance like LPS over northwest Bay and the monsoon trough extending from the LPS to west-northwesterly direction, there is interaction between the basic westerly monsoon flow and the LPS. Due this interaction, there is maximum low level convergence and vertical motion of moist air in the left front quadrant or southwest sector of LPS. As Orissa lies in the left front quadrant or southwest sector of this LPS, it gets heavy to very heavy rainfall activity due to such type of LPS. In the absence of any LPS over adjoining Bay of Bengal along the monsoon trough, the basic monsoon flow is generally westerly. These westerlies do not yield good rainfall over Orissa as these 

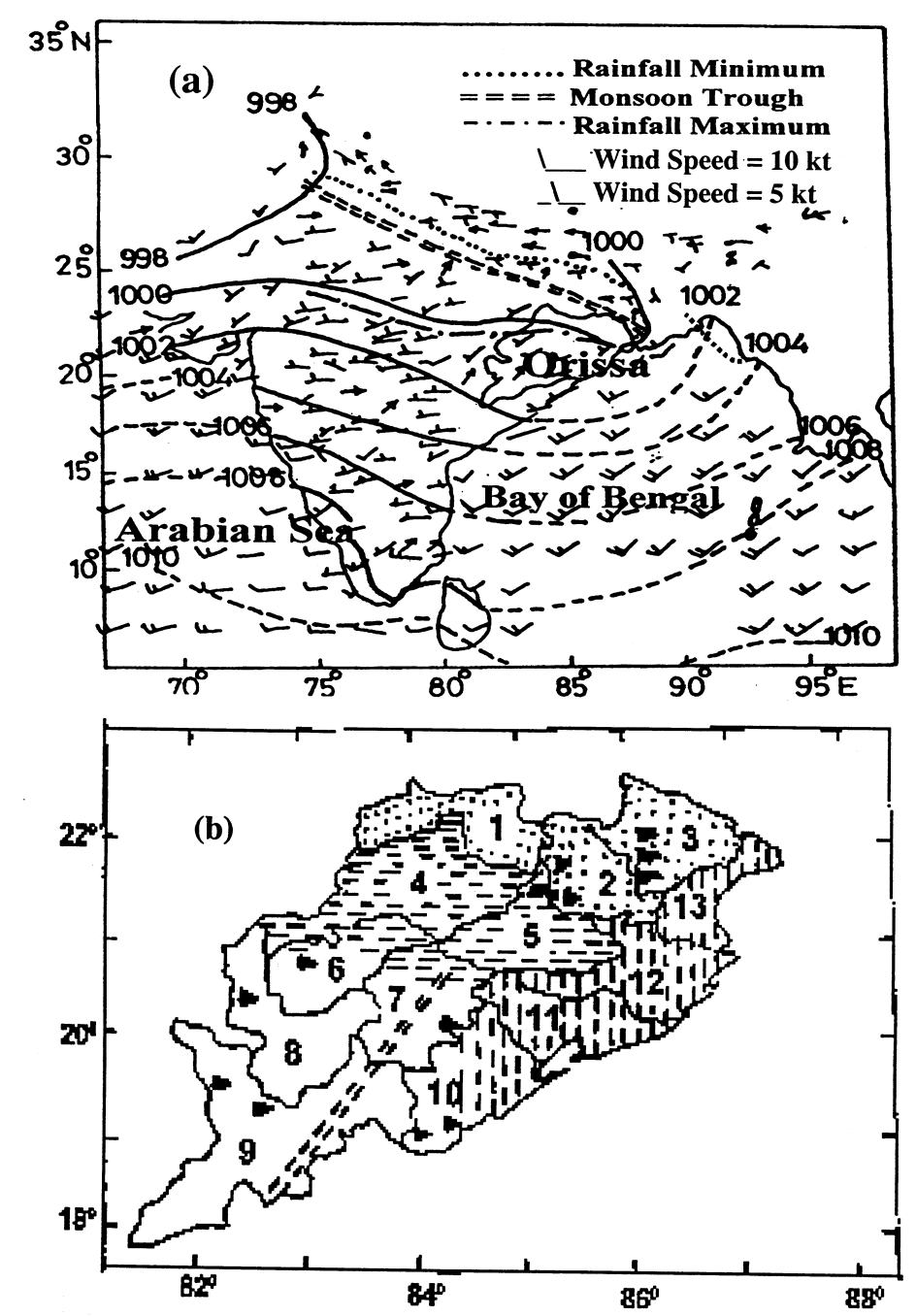

\section{$\square$ Southwest hilly region ||| Coastal Plain $\ldots$. Northern upland $\equiv \equiv$ Central river basin $===$ Axis of Eastern Ghat}

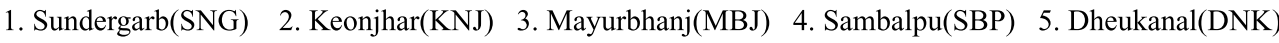

6. Bolangir(BNG) 7. Phulbani(PLB) 8. Kalahandi(KLH) 9. Koraput(KRP) 10. Ganjam(GNJ)

11. Puri(PRI) 12. Cuttack(CTK) 13. Balasore(BLS)

Figure 1. (a) Mean sea level isobaric pattern (in hPa) and mean wind (in knots) in representative month of July, plotted according to WMO code over Indian region and (b) physiographical map of Orissa.

are relatively continental air mass from west coast of India to Orissa.

The physiographical regions of Orissa are shown in figure 1(b). Broadly, Orissa consists of four physiographical regions, viz., (i) coastal plain (ii) northern upland (iii) central river basin and (iv) southwest hilly region. Some of the hill peaks in northern upland and southwest hilly region are as high as $1000 \mathrm{~m}$ to $2000 \mathrm{~m}$. Though the Eastern Ghat extends from Tamilnadu in the southwest to north Orissa in the northeast, it is most prominent in north Andhra Pradesh and south Orissa region. The coastal plain comprises of Balasore (BLS), Cuttack (CTK), Puri (PRI) and coastal areas of Ganjam (GNJ) districts. The southwest hilly region comprises of interior GNJ, Koraput (KRP), Kalahandi (KLH) and two thirds of Bolangir (BLR) and Phulbani (PLB) districts. GNJ and eastern part of KRP district lie on the eastern side of Eastern Ghat. The northern upland consists of Sundargarh (SNG), Keonjhar (KNJ) and Mayurbhanj (MBJ) districts and northern most part of Dhenkaral (DNK) district. The central river basin consists of Sambalpur (SBP) district and remaining areas of BLR, PLB and DNK districts. All the above-mentioned districts are undivided districts of Orissa. The districts of CTK and BLS constitute north coastal Orissa and PRI and GNJ districts constitute south coastal Orissa. Similarly KLH, BLR, KRP and PLB districts 
constitute south interior Orissa and the remaining districts constitute north interior Orissa. Due to the orographic interaction of Eastern Ghat, western side of Eastern Ghat becomes windward region with the basic monsoon flow as westerly in association with the synoptic disturbance over north Bay and hence gets more intense rainfall. When the disturbance lies southward, e.g., over west central Bay, the basic monsoon flow becomes easterly over Orissa and hence western side of Eastern Ghat becomes lee side and gets less intense rainfall. So the very heavy rainfall over Orissa during monsoon season depends on the intensity, movement and region of occurrence of synoptic disturbances like LPS and the physiography of Orissa. However, most of the LPS develop over the NW Bay and move west-northwestwards along the monsoon trough across Gangetic West Bengal or Orissa. As a result, Orissa experiences very heavy rainfall leading sometimes to flood in different river catchments.

Considering all the above facts, an attempt is made to find out the characteristic features of spatial and temporal variability of frequency and intensity of very heavy rainfall over Orissa. For this purpose, the very heavy rainfall events with daily 24 hours accumulated rainfall $\geq 125 \mathrm{~mm}$ recorded at 0830 IST over different rain gauge stations in Orissa during monsoon months (June-September) are collected for the period of 20 years (19801999). The rain gauge stations selected for the study are given in figure 2(a). As the data are not available for all the selected stations continuously for a period of 20 years (1980-1999), the stations with at least 10 years data are considered in the study. The data are quality checked by comparing with rainfall recorded over surrounding stations.

Different statistical characteristics like mean frequency distribution, mean intensity distribution and variability in frequency and intensity of the very heavy rainfall events, etc. are calculated and analysed. The variability in the frequency of very heavy rainfall is analysed by finding out the distribution of the highest frequency, lowest frequency, range and the coefficient of variation in the frequency of very heavy rainfall during different monsoon months and the season as a whole. The mean intensity of very heavy rainfall events over a station is the mean daily rainfall, calculated by considering only the days of very heavy rainfall over that station. The variation in intensity of very heavy rainfall is analysed by calculating the $\mathrm{CV}$ in daily accumulated 24 hours rainfall $\geq 125 \mathrm{~mm}$. The recent trends in frequency of very heavy rainfall events are analysed by calculating linear trend coefficients in the frequency of very heavy rainfall events for all the selected stations.
The synoptic systems with their intensities and regions of occurrence are collected from different weather reports published by India Meteorological Department (IMD) to find out the causative systems of very heavy rainfall. As the LPS are the major synoptic disturbances to cause very heavy rainfall leading some times to flood in Orissa, the characteristic features of LPS in relation to very heavy rainfall events like the average numbers of days of occurrence of LPS (LPS days) over different regions, movement of LPS developing over Bay of Bengal, percentage frequency of very heavy rainfall events caused by LPS and most favourable regions of LPS to cause very heavy rainfall at different places over Orissa are analysed. The LPS days over west central (WC) Bay of Bengal off north coastal Andhra Pradesh, northwest (NW) Bay of Bengal, northeast (NE) Bay of Bengal, Orissa (ORS), Gangetic West Bengal (GWB), Bangladesh (BDS), Jharkhand (JKD) and east Madhya Pradesh and Chhatishgarh (EMPC) are considered in the analysis (figure 2b) as LPS over these regions mostly cause very heavy rainfall over Orissa. A day is considered as an LPS day over a region if a low depression/deep depression/cyclonic storm is detected over that region according to 0300UTC synoptic observation of that day. The percentage frequency of very heavy rainfall over a station due to LPS is calculated from the ratio of the frequency of very heavy rainfall due to LPS to the total frequency of very heavy rainfall over that station. The most favourable regions of occurrence of LPS to cause very heavy rainfall over the selected stations in Orissa are found out by considering the percentage contributions of LPS over different regions under consideration as shown in figure 2(b) to the total frequency of very heavy rainfall events. Also the correlation coefficients (CC) between the frequency of very heavy rainfall events over the selected stations under consideration as shown in figure 2(a) and the number of LPS days over different regions under consideration as shown in figure 2(b) are calculated and analysed to find out their degree of association.

\section{Results and discussion}

The frequency of occurrence of LPS over different regions under consideration and the movement of the LPS developing over the Bay of Bengal during summer monsoon season over the period of 1980-1999 are analysed in section 3.1. The mean frequency distribution and the variation in frequency of very heavy rainfall are analysed and discussed in section 3.2 and section 3.3 respectively. The mean intensity distribution and the interevent variation of intensity of very heavy rainfall 
(a)



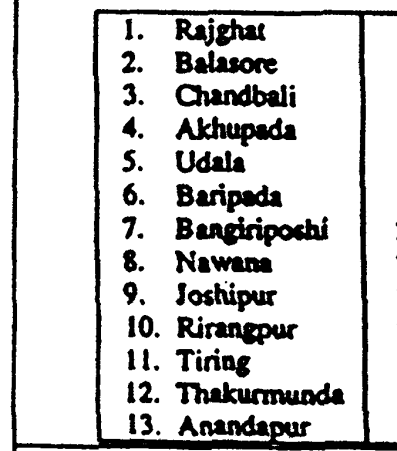

\begin{tabular}{|c|c|}
\hline $\begin{array}{l}\text { 14. Telkoi } \\
\text { 15. Keonjhar } \\
\text { 16. Swampatna } \\
\text { 17. Champua } \\
\text { 18. Tenea } \\
\text { 19. Lahuaipara } \\
\text { 20. Panposh } \\
\text { 21. Sunderearh. } \\
\text { 22. Paikmal } \\
\text { 23. Sohela } \\
\text { 24. Ambabhona } \\
\text { 25. Sambelpur } \\
\text { 26. Jharsuguda }\end{array}$ &  \\
\hline
\end{tabular}

26. Jursuruda 39. Joupan

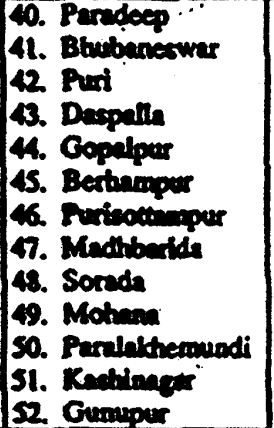

41. Bubingeswer

4. Prientin

47. Mindtbuida

48. Sordh

S1. Kontingt: 22. Gumper
53. Oudini
S4. Antodols
55. Blenm Outuck
S6. Potton i
57. Miliongin
58. Nowmangoper
99. Homentome
60. Modmper Rarpur
61. Titilngerh
62. Bolangir
63. Sonepur
64. Funberi

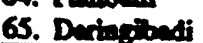

1. North East Bay (NE Bay)

2. North West Bay (NW Bay)

3. West Central Bay (WC Bay)

4. North Coastal Andhra Pradesh (NCAP)

5. Orissa (ORS)

6. East Madhya Pradesh and Chattishgarh (EMPC)

7. Jharkhand (JKD)

8. Gangetic West Bengal (GWB)

9. Bangladesh (BDS)

Figure 2. (a) Selected raingauge stations in Orissa for analysis and (b) regions of low pressure systems under consideration.

are analysed and discussed in section 3.4 and section 3.5 respectively. The role of LPS on very heavy rainfall over Orissa is analysed and discussed in section 3.6. The recent trends in the frequency of very heavy rainfall over the selected stations in Orissa are analysed and discussed in section 3.7. 

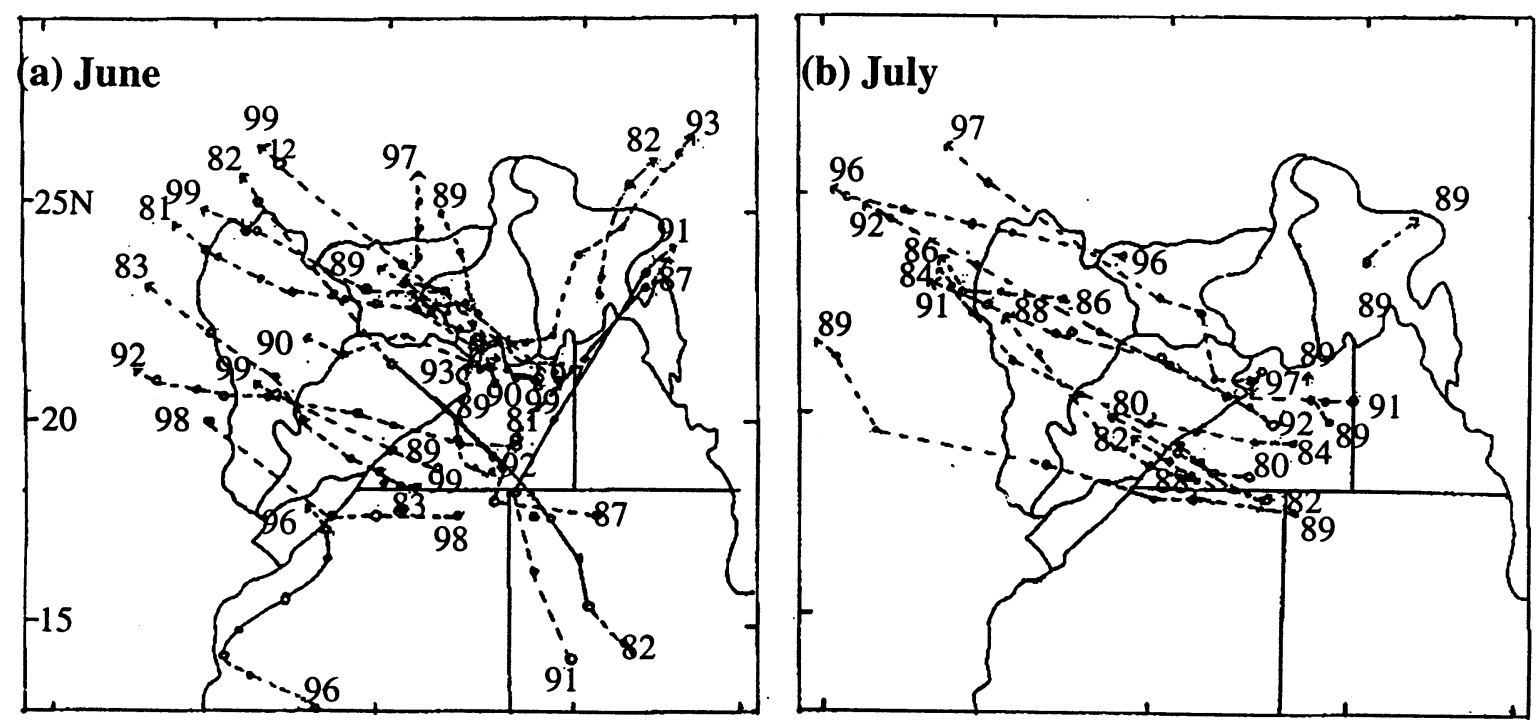

\section{(c) August}
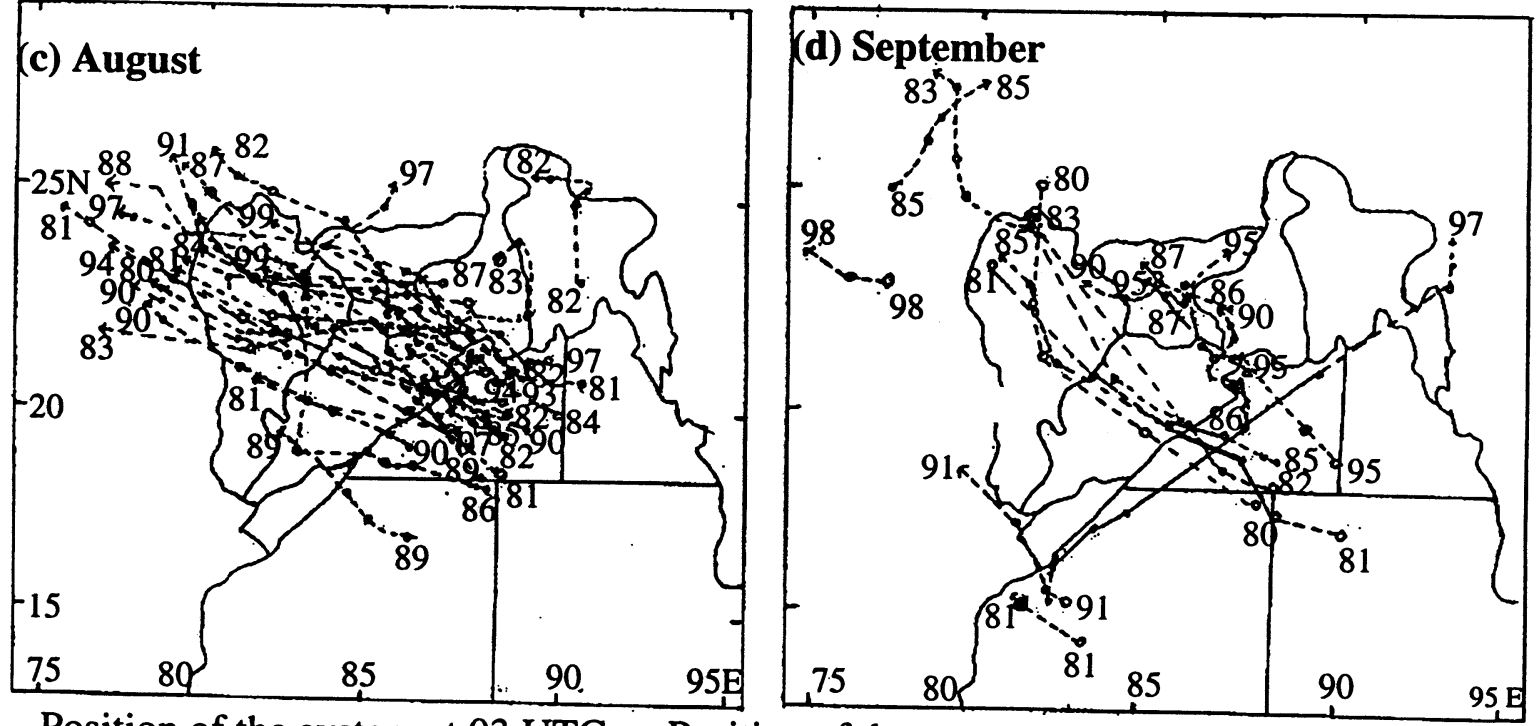

oPosition of the system at 03 UTC . Position of the system at 12 UTC

---- Depression Cyclonic storm Severe cyclonic storm

\section{Direction of movement/Region of dissipation}

The figures in the begining/end of the tracks indicate year of occurrence of the system

Figure 3. The tracks of cyclonic storms and depressions developing over Bay of Bengal during monsoon season (June-September) over a period of 20 years (1980-1999).

\subsection{Frequency of occurrence and movement of LPS}

The tracks of cyclonic storms and depressions (cyclonic disturbances) developing over Bay of Bengal during summer monsoon months over the period of 1980-1999 are shown in figure 3. Unlike the cyclonic disturbances, the centre of monsoon lows over the sea is not well defined. Hence, the frequencies of the monsoon lows developing over different regions of Bay of Bengal and crossing different coastal regions under consideration are analysed. The results are shown in table 1. Mooley and Shukla (1989) have studied characteristics of LPS and found that the frequency of LPS has no relation with Indian summer monsoon rainfall (ISMR) rather a good positive correlation exists between the total number of LPS days and ISMR. 
Table 1. The frequency distribution of monsoon lows developing over Bay of Bengal and crossing different coastal regions of Orissa during different monsoon months (June-September) over a period of 20 years (1980-1999).

\begin{tabular}{|c|c|c|c|c|c|c|c|}
\hline \multirow[b]{2}{*}{ Period } & \multirow{2}{*}{$\begin{array}{l}\text { Region } \\
\text { formation }\end{array}$} & \multirow{2}{*}{$\begin{array}{l}\text { Subsequent } \\
\text { regions over Bay }\end{array}$} & \multicolumn{5}{|c|}{ Coastal region crossed by monsoon low } \\
\hline & & & NCAP & Orissa & GWB & Bangladesh & Total \\
\hline \multirow[t]{6}{*}{ June } & NE Bay & - & 0 & 0 & 0 & 1 & 1 \\
\hline & NE Bay & NW Bay & 0 & 0 & 2 & 0 & 2 \\
\hline & NW Bay & - & 0 & 6 & 6 & 2 & 14 \\
\hline & WC Bay & - & 0 & 0 & 0 & 0 & 0 \\
\hline & WC Bay & NW Bay & 0 & 2 & 0 & 0 & 2 \\
\hline & Total $(\%)$ & & $0(0 \%)$ & $8(42 \%)$ & $8(42 \%)$ & $3(16 \%)$ & $19(100 \%)$ \\
\hline \multirow[t]{5}{*}{ July } & NE Bay & - & 0 & 0 & 0 & 0 & 0 \\
\hline & NW Bay & - & 0 & 13 & 8 & 0 & 21 \\
\hline & WC Bay & - & 3 & 0 & 0 & 0 & 3 \\
\hline & WC Bay & NW Bay & 0 & 0 & 1 & 0 & 1 \\
\hline & Total $(\%)$ & & $3(12 \%)$ & $13(52 \%)$ & $9(36 \%)$ & $0(0 \%)$ & $25(100 \%)$ \\
\hline \multirow[t]{7}{*}{ August } & NE Bay & - & 0 & 0 & 0 & 1 & 1 \\
\hline & NE Bay & NW Bay & 0 & 2 & 1 & 1 & 4 \\
\hline & NW Bay & - & 0 & 20 & 6 & 2 & 28 \\
\hline & NW Bay & WC Bay & 1 & 0 & 0 & 0 & 1 \\
\hline & WC Bay & - & 5 & 1 & 0 & 0 & 6 \\
\hline & WC Bay & NW Bay & 0 & 0 & 0 & 1 & 1 \\
\hline & Total (\%) & & $6(15 \%)$ & $23(56 \%)$ & $7(17 \%)$ & $5(12 \%)$ & $41(100 \%)$ \\
\hline \multirow[t]{7}{*}{ September } & NE Bay & - & 0 & 0 & 0 & 1 & 1 \\
\hline & NE Bay & NW Bay & 0 & 2 & 0 & 0 & 2 \\
\hline & NW Bay & - & 0 & 15 & 10 & 0 & 25 \\
\hline & NW Bay & WC Bay & 1 & 0 & 0 & 0 & 1 \\
\hline & WC Bay & - & 9 & 0 & 0 & 0 & 9 \\
\hline & WC Bay & NW Bay & 0 & 1 & 0 & 0 & 1 \\
\hline & Total (\%) & & $10(26 \%)$ & $18(46 \%)$ & $10(26 \%)$ & $1(2 \%)$ & $39(100 \%)$ \\
\hline Season & NE Bay & - & 0 & 0 & 0 & 3 & 3 \\
\hline \multirow{6}{*}{ (Jun.-Sep.) } & NE Bay & NW Bay & 0 & 4 & 3 & 1 & 8 \\
\hline & NW Bay & - & 0 & 54 & 30 & 4 & 88 \\
\hline & NW Bay & WC Bay & 2 & 0 & 0 & 0 & 2 \\
\hline & WC Bay & - & 17 & 1 & 0 & 0 & 18 \\
\hline & WC Bay & NW Bay & 0 & 3 & 1 & 1 & 5 \\
\hline & Total (\%) & & $19(15 \%)$ & $62(50 \%)$ & $34(27 \%)$ & $9(7 \%)$ & $124(100 \%)$ \\
\hline
\end{tabular}

Hence in this study, the number of LPS days over different regions under consideration are analysed. The average number of LPS days over different regions under consideration based on the data of 1980-1999 ARE shown in figure 4.

According to figure 3 and table 1 , the LPS mostly forms over the NW Bay and move west-northwestwards across Orissa followed by GWB. However, the movement of LPS is more variable and hence less consistent during June and September as the monsoon trough is not well marked during these months due to onset and withdrawal phases of monsoon respectively. The average frequency of LPS developing over Bay of Bengal is maximum in August among different monsoon months. According to figure 4, the average number of LPS days is maximum over the NW Bay among different regions under consideration during all the monsoon months and the season as a whole. As (i) the LPS are formed along the monsoon trough, (ii) they mostly move west-northwestwards/northwestwards along the monsoon trough and (iii) the monsoon trough shifts southwards as the season advances, GWB and Bangladesh experience maximum number of LPS days during June, WC Bay off NCAP and NCAP experience maximum number of LPS days during September and all other regions under consideration experience maximum number of LPS days during August.

\subsection{Frequency distribution of very heavy rainfall}

In general, the frequency of very heavy rainfall events is higher in August followed by July, June and September (figure 5) due to the fact that the number of LPS days causing very heavy rainfall over Orissa is maximum during August (figure 4). During July and August, the very heavy rainfall occurs by the interaction of basic monsoon flow and 

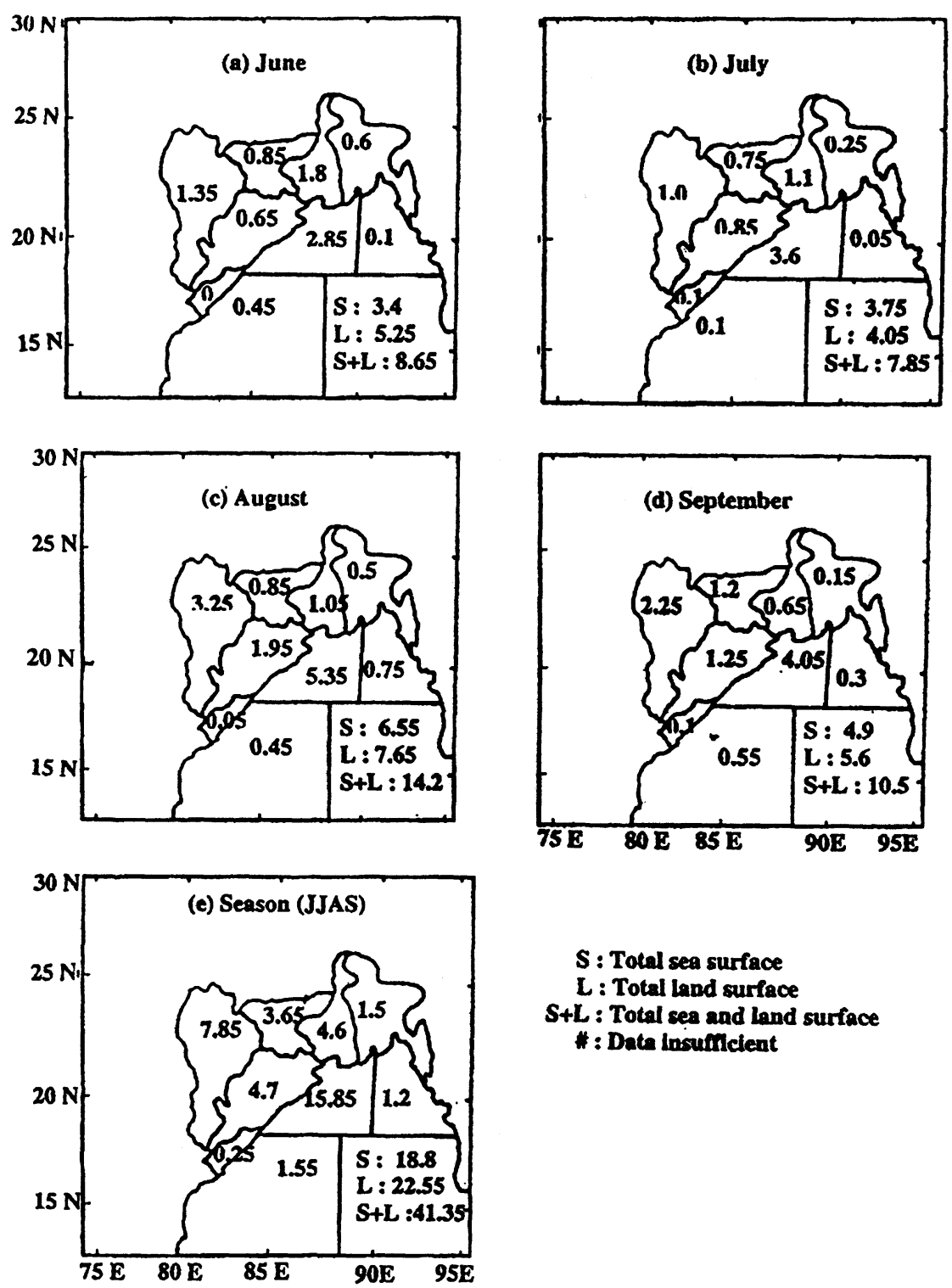

\author{
$S$ : Total sea surface \\ $L:$ Total land surface \\ $S+L$ : Total sea and land surface \\ * : Data insumelent
}

Figure 4. The average numbers of LPS days over different regions under consideration as shown in figure 2(b) during different monsoon months and the season based on data of 20 years $(1980-1999)$.

the LPS developing mostly over NW Bay, GWB and north Orissa with the monsoon trough from the system extending to west-northwesterly direction. Most parts of Orissa lie in the southwest sector, which is the maximum convergence zone of these LPS. According to Rajamani and Rao (1981), the southwest sector of a westward moving monsoon depression gets more intense rainfall due to maximum low level convergence and vertical motion. The monsoon trough is well established during July and August, leading to more interaction of basic monsoon flow with the orography and the synoptic disturbances like LPS. During July, August and season as a whole, there is a region of higher frequency, extending from north coastal Orissa to southwestern part of SBP. It may be attributed to the fact that (i) most of the LPS develop over NW Bay and move west-northwestwards/northwestwards along the monsoon trough (figure 3 and table 1), (ii) very heavy rainfall occurs by the interaction of basic monsoon flow with these LPS and orography and (iii) most intense rainfall takes place over the region, south of the monsoon trough due to maximum low level convergence and vertical motion over the region (Raghavan 1973; Pathan 1993). As this region covers central river basin and coastal plain, it is affected by frequent floods due to very heavy rainfall. The above orientation in the maximum belt of the mean frequency is not observed during June and September as the monsoon trough is less marked due to onset and withdrawal phases 

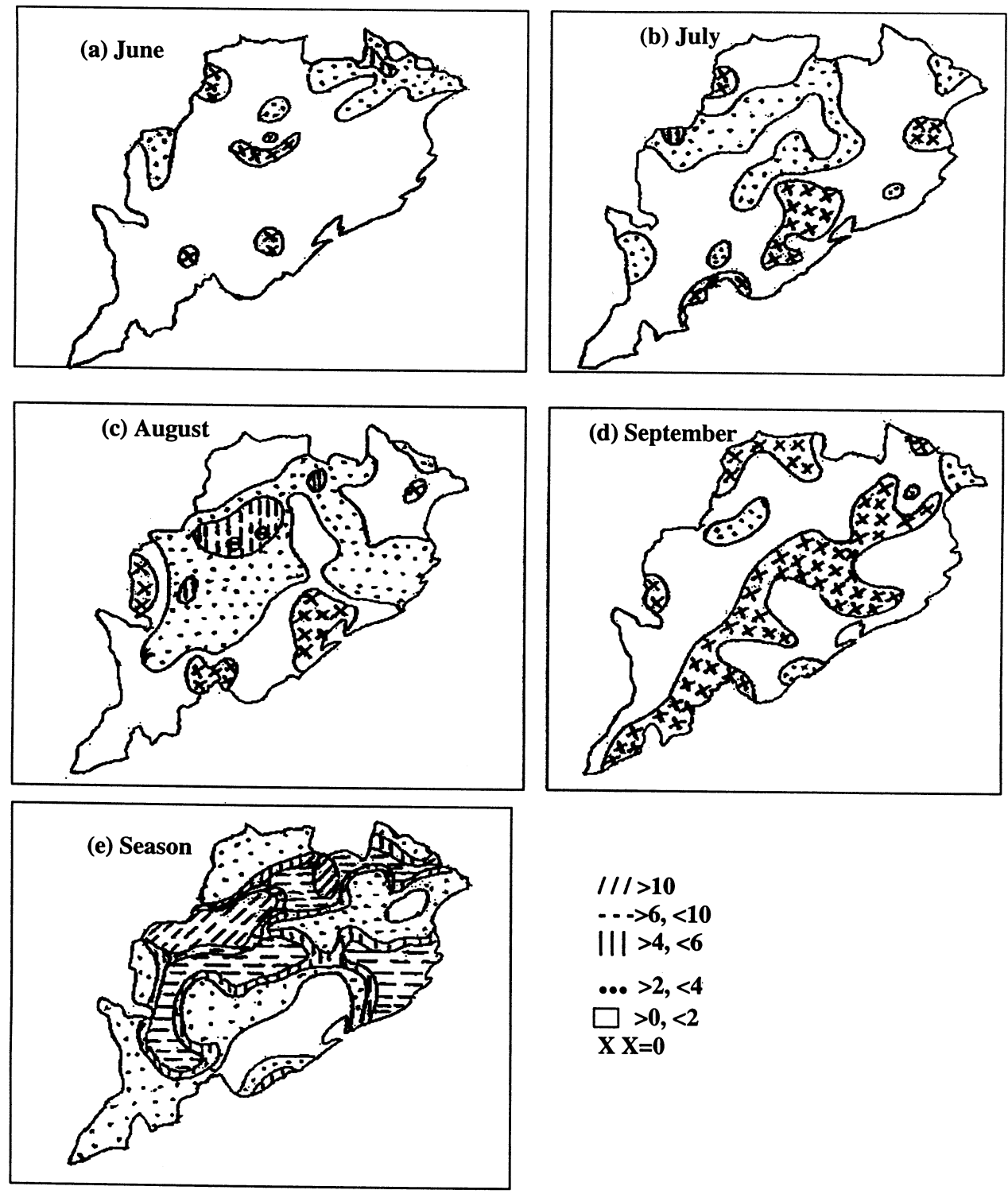

Figure 5. Mean frequency distribution of very heavy rainfall over Orissa during different monsoon months and the season.

of monsoon during June and September respectively.

During the month of June, there is significant impact of orography in the northern upland and minimum impact in the rest of the state. During the month of September, even though there is a well marked region of less frequency of very heavy rainfall along the Eastern Ghat extending from southwest to northeast, there is no well defined region of higher frequency of very heavy rainfall on the eastern side of Eastern Ghat except some pockets in south coastal Orissa. As LPS mostly develops over NW Bay and move west-northwestwards along the monsoon trough during July and August (figure 3 and table 1), the western and eastern sides of Eastern Ghat become windward and lee side respectively with basic westerly monsoon flow over the region. Hence, there is enhanced rainfall activity on western side leading to two distinct regions of maxima and minima in the frequency of very heavy rainfall over western and eastern sides of the Eastern Ghat respectively during July, August and the monsoon season.

\subsection{Variability in frequency of very heavy rainfall}

The results of variability analysis considering the highest frequency, lowest frequency and range in frequency of very heavy rainfall over different stations during different monsoon months and the season as a whole are analysed and discussed in section 3.3.a. The coefficients of variation in the frequency of very heavy rainfall over different stations during different monsoon months and the 
season as a whole are analysed and discussed in section 3.3.b.

\section{3a Variability of the highest frequency, lowest frequency and range in frequency of very heavy rainfall}

The lowest frequencies of different stations in Orissa are equal to zero during all individual months and not presented/discussed. Thus only the distribution of range in seasonal frequency of very heavy rainfall is different from that of highest seasonal frequency. The higher range in frequency and the highest frequency of very heavy rainfall occur over the region, generally extending from CTK district coast in the southeast towards western part of SBP district in the northwest (figure 6) during all the months and the season as a whole, being more significantly so during season as a whole. The highest frequency over this region may be attributed to the fact that (i) most of the causative systems like LPS form over the NW Bay with monsoon trough extending west-northwestwards across GWB or Orissa (figure 3 and table 1) and (ii) the region lying in the southwest sector of the LPS gets most intense rainfall due to maximum low level convergence in the sector. Also the range in seasonal frequency is higher over western side of the Eastern Ghat, along the Eastern Ghat and some parts of northern upland. It may be attributed to (i) the enhancement of rainfall over these areas due to interaction of orography with the basic westerly monsoon flow over the region and the LPS and (ii) variation in orographic enhancement of rainfall due to large variation in the frequency of formation, region of occurrence and intensity of synoptic disturbances like LPS.

\section{3b Coefficient of variation (CV) in the frequency of very heavy rainfall}

To find out the interannual variation in the frequency of very heavy rainfall, the CV of frequency of very heavy rainfall are calculated and results are shown in figure 7 . The CV is very high $(>100 \%)$ over Orissa during all individual months and over most parts of Orissa during the season as a whole, indicating that there is large interannual variation in the frequency of very heavy rainfall over any individual station in Orissa. Among different monsoon months, the $\mathrm{CV}$ is higher during September followed by June and less during August followed by July. It may be due to large interannual variation in frequency of causative systems like LPS during June and September and less interannual variation during July and August. The CV is higher over eastern part of Eastern Ghat in southwest hilly region during all individual months except September (figure 7). During September, $\mathrm{CV}$ is less over eastern parts of Eastern Ghat. It may be attributed to the fact that during all the months except September, the impact of LPS in causing very heavy rainfall over the eastern side of Eastern Ghat is highly variable due to higher variation in frequency of formation and movement of LPS. During September, the LPS has more tendency to form over southern latitude, i.e., over WC Bay (figure 3 and table 1) due to southward shifting of the monsoon trough. With the LPS over WC Bay, the basic westerly monsoon flow changes over to easterly over Orissa. Hence the eastern side of Eastern Ghat becomes windward side and gets very heavy rainfall. During September, the region of lower $\mathrm{CV}$ is oriented from southwest to northeast along the coast, which may be attributed to the facts that (i) the number of LPS days over WC Bay or WC and adjoining NW Bay is maximum with minimum variability in September among different months (figure 4), (ii) eastern side of Eastern Ghat becomes windward region for these LPS as the basic monsoon flow over this region becomes easterly and (iii) the region of most intense rainfall due to these LPS is confined mostly to coastal plain and eastern side of Eastern Ghat as the monsoon trough is less marked during September due to withdrawal phase of monsoon. During the season as a whole, there is no significant orientation in the region of maxima or minima except that there is a contrasting difference with higher $\mathrm{CV}$ on the eastern side and lower $\mathrm{CV}$ on the western side of Eastern Ghat indicating large interannual variability in the frequency of very heavy rainfall over eastern side of Eastern Ghat. It may be due to large interannual variation in the number of LPS days over WC Bay, which is the favourable region of LPS to cause very heavy rainfall over eastern side of Eastern Ghat. Some areas in the eastern side of northern upland and adjoining areas also experience relatively higher $\mathrm{CV}$ due to variation in orographic enhancement of rainfall in association with large scale variation in the frequency, intensity, region of occurrence and movement of synoptic disturbances like LPS. There is a region of lower CV extending from central part of coastal Orissa to northwest Orissa during July and August. It may be due to (i) less interannual variation of LPS days over NW Bay during July and August and (ii) well marked monsoon trough only during July and August.

\subsection{Intensity of very heavy rainfall}

During all the months and the season, the average intensity of very heavy rainfall is relatively less 

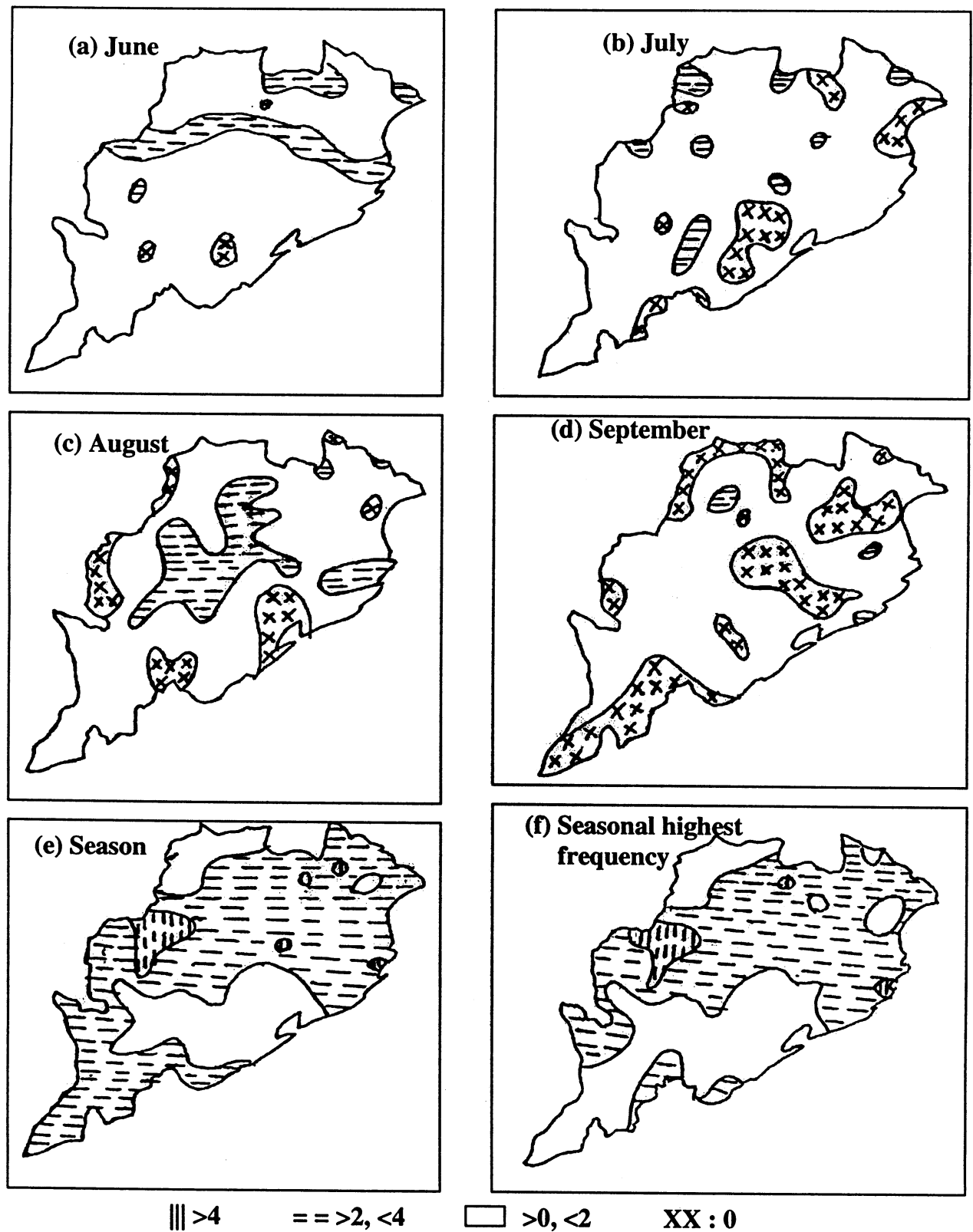

Figure 6. (a-e) Range in frequency of very heavy rainfall over Orissa during different monsoon months and the season and (f) seasonal highest frequency of very heavy rainfall during monsoon season.

over eastern part than over western and central parts of Eastern Ghat with the difference in intensities being less significant during June (figure 8). There is southeast to northwest orientation of the region with higher intensity, extending from coastal Orissa to western Orissa during all the months and the season, being less significant during September. It may be attributed to the fact that (i) the causative systems like LPS mostly form over NW Bay and neighbourhood, (ii) they move west-northwestwards along the monsoon trough (figure 3 and table 1) and (iii) the region, a little south of the monsoon trough gets more intense rainfall due to maximum low level convergence. As this region covers central river basin and coastal plain, it is affected by frequent floods due to more intense very heavy rainfall. The number of LPS days over WC Bay or WC and adjoining NW Bay is more in September than in other months (figure 4). The eastern side of Eastern Ghat becomes windward region for these LPS with basic westerly monsoon flow over the region changed over to easterly and hence gets more rainfall due to this LPS. As the monsoon trough is less marked during the month of September due to withdrawal phase of monsoon, the very heavy rainfall is more confined to coastal plain and eastern side of Eastern Ghat and southeast-northwest orientation in region of 

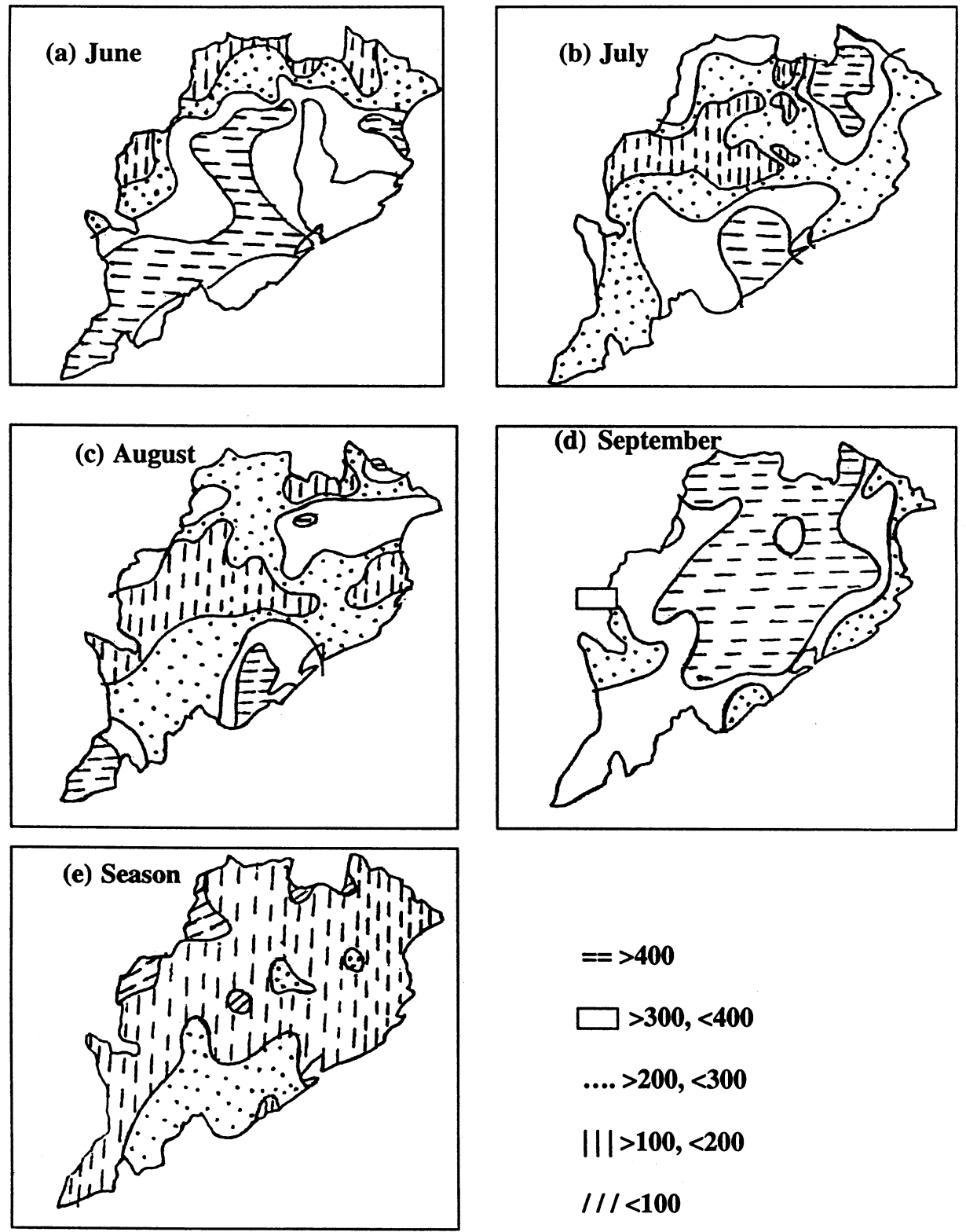

Figure 7. Coefficients of variation (\%) in the frequency of very heavy rainfall during different monsoon months and the season.

higher intensity as observed in other months is not seen during September. Some parts in eastern side of northern upland and adjoining areas get less intense rainfall during all individual months and the season as a whole, as this region becomes leeward side due to hill peaks in the neighbourhood.

\subsection{Coefficient of variation (CV) in the intensity of very heavy rainfall}

To find out the inter-event variation in intensity of very heavy rainfall, the CV in intensity of very heavy rainfall are analysed. During all individual months and the season as a whole, the higher mean intensity is associated with higher $\mathrm{CV}$ and vice versa. The CV is generally higher during July and August than in June and September (figure 9). The spatial range (highest-lowest) in CV of intensity is maximum during August (64\%) followed by July (47\%), June (38\%) and September (28\%). During the season as a whole, the spatial range in CV of intensity is $58 \%$ (not shown in figure). Hence the intensity is more variable both spatially and temporally during July and August than in June and September. The monsoon trough is well marked during July and August only and it is less marked during June and September due to onset and withdrawal phases of monsoon respectively. As a result, small scale synoptic systems like cyclonic circulation extending upto lower/middle tropospheric 

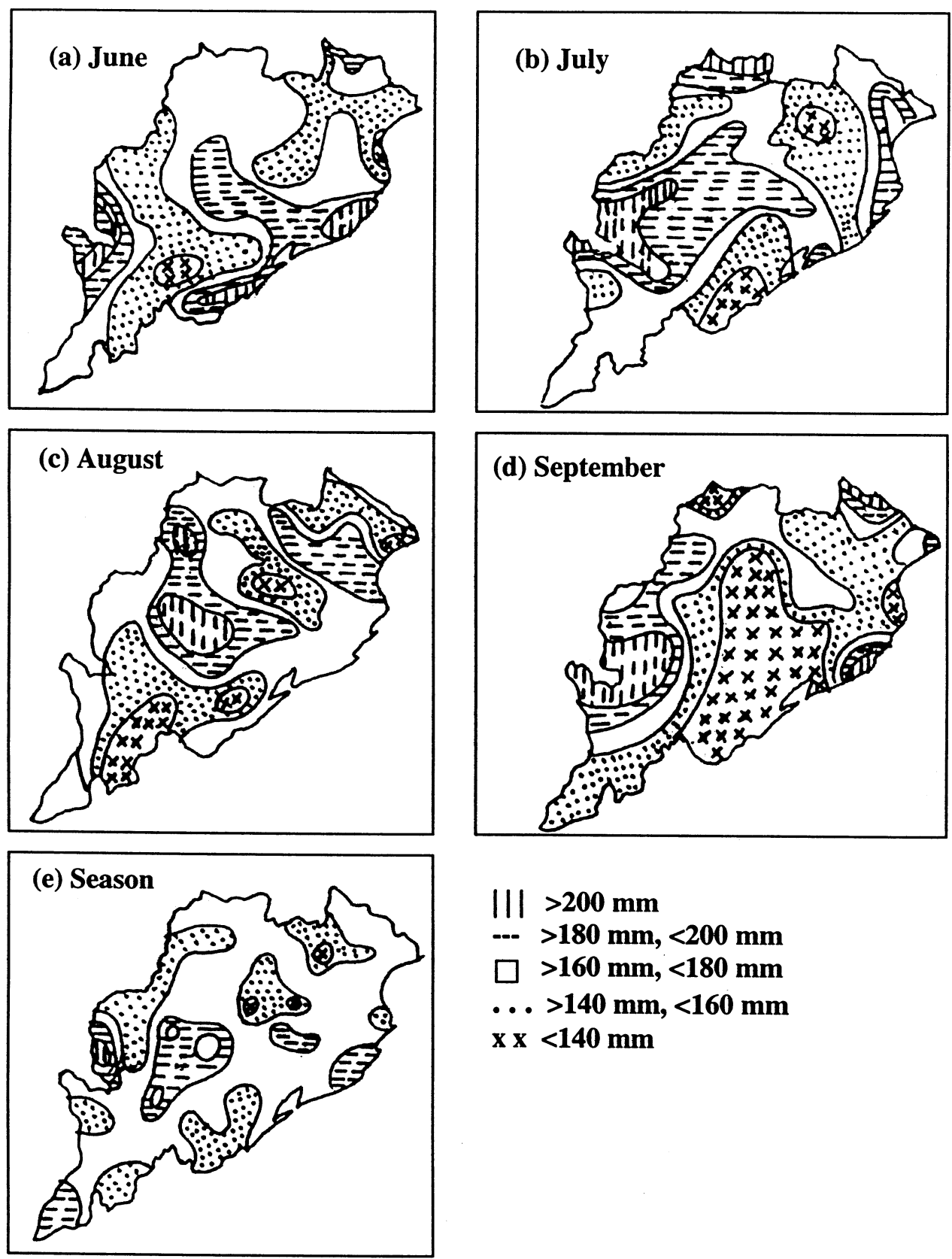

$$
\begin{aligned}
& \text { III }>200 \mathrm{~mm} \\
& -->180 \mathrm{~mm},<200 \mathrm{~mm} \\
& \square>160 \mathrm{~mm},<180 \mathrm{~mm} \\
& \ldots .>140 \mathrm{~mm},<160 \mathrm{~mm} \\
& \times \times<140 \mathrm{~mm}
\end{aligned}
$$

Figure 8. Mean intensity of 24 hours daily accumulated very heavy rainfall (in $\mathrm{mm}$ ) over Orissa during different monsoon months and the season.

level (cycir) over NW Bay, etc. can cause sometimes very heavy rainfall over isolated places in Orissa, specially over southwest hilly region of Eastern Ghat due to their interaction with basic monsoon flow and orography during July and August. Therefore synoptic systems causing very heavy rainfall range from small scale synoptic systems like cycir to large scale synoptic disturbances like depressions/cyclonic storms. Hence, there is large variability in intensity of very heavy rainfall during July and August. Specially, the intensity is more variable over central and western parts than over eastern side of Eastern Ghat. The southeast to northwest orientation in region of less CV in intensity across central Orissa is significantly seen during July and August like the CV in the frequency of very heavy rainfall.

\subsection{Low pressure systems (LPS) and very heavy rainfall}

The percentage frequency of very heavy rainfall due to LPS and the most favourable region of occurrence of LPS to cause very heavy rainfall over Orissa are analysed and discussed in section 3.6.a 

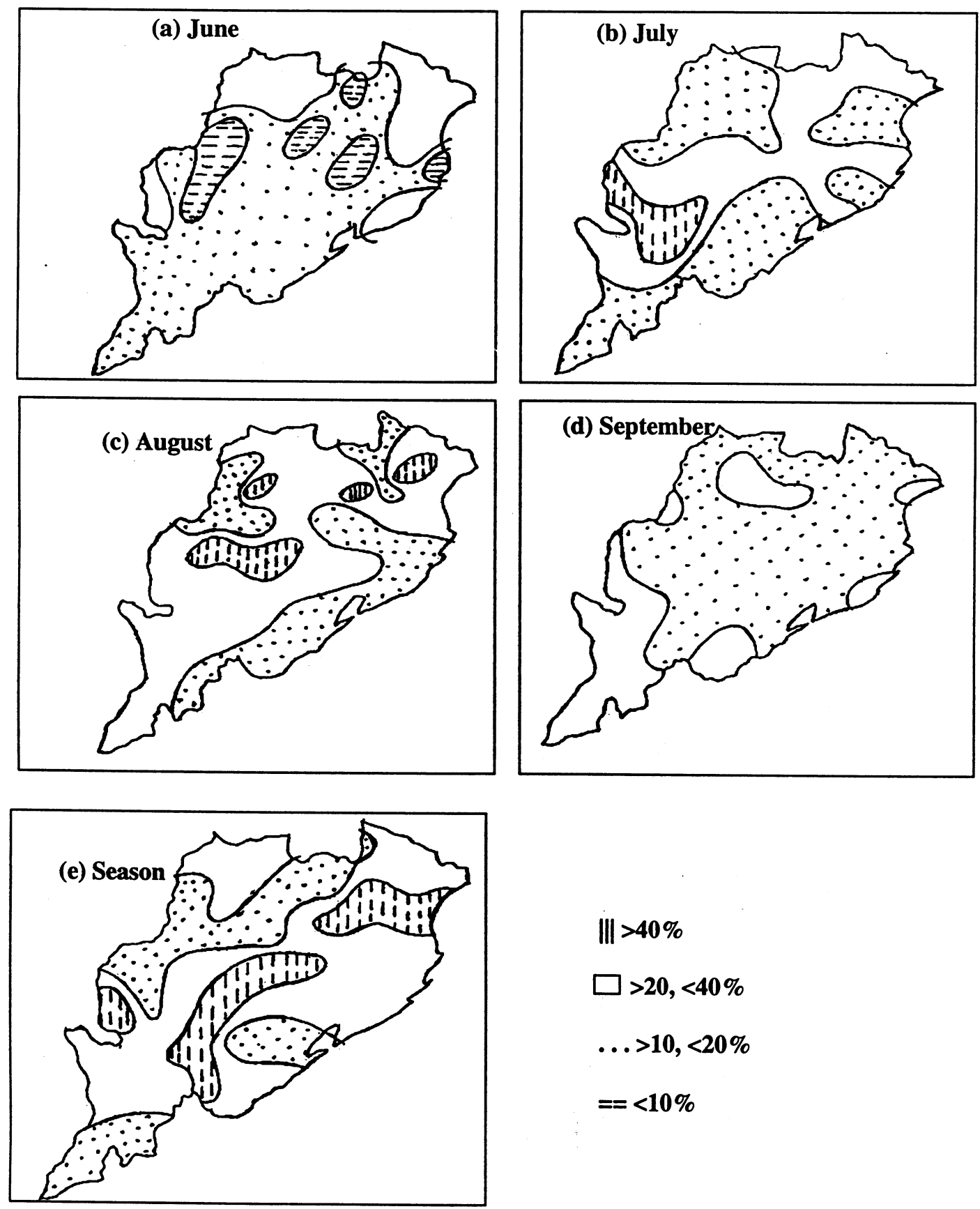

Figure 9. Coefficients of variation (\%) in intensity of very heavy rainfall over Orissa during different monsoon months and the season.

and section 3.6.b respectively. The results of correlation analysis between the frequency of very heavy rainfall over different stations in Orissa and the number of LPS days over different regions under consideration as shown in figure 2(a) are discussed in section 3.6.c.

\section{6a Percentage frequency of very heavy rainfall caused by LPS}

The spatial distribution of percentage frequency of very heavy rainfall caused by LPS out of total frequency of very heavy rainfall is shown in figure 10 . The percentage frequency is maximum during September followed by June, August and July. As monsoon trough is not well established over Indian region during June and September due to onset and withdrawal phases of monsoon respectively, the interaction of small scale synoptic systems like cycir with the basic monsoon flow and orography is comparatively less during June and September to cause the very heavy rainfall. So the very heavy rainfall is more dependent on the LPS during these months. The percentage frequency is 

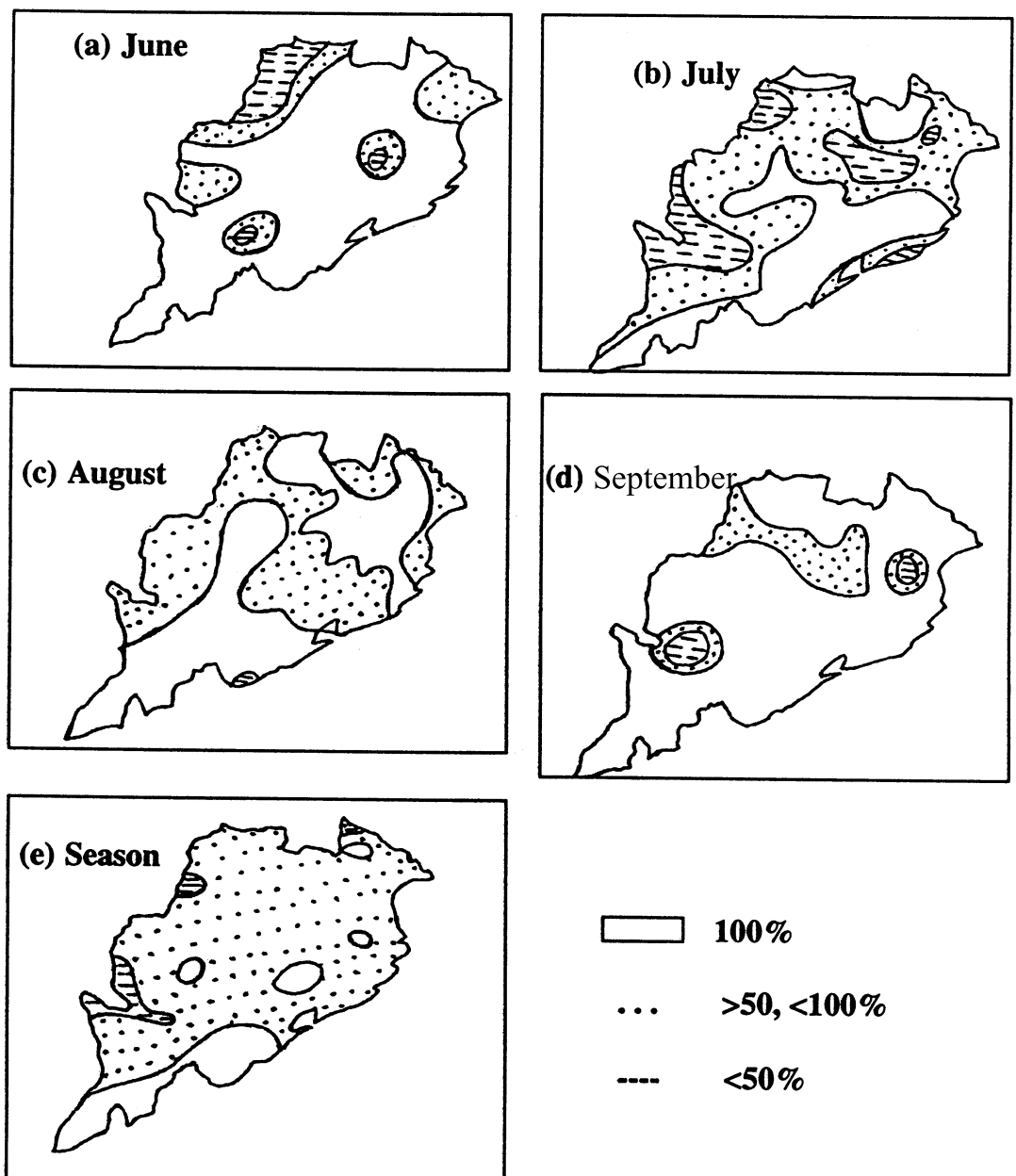

Figure 10. Percentage frequency of very heavy rainfall over Orissa caused by low pressure systems during different monsoon months and the season.

higher over eastern side than over western and central belt of Eastern Ghat in all individual months and the season as a whole with the contrast being more significant in July and August. The western and central belt of Eastern Ghat can get very heavy rainfall due to interaction of small scale synoptic systems like cycir over NW Bay, etc. with basic westerly flow of monsoon and orography due to Eastern Ghat specially during July and August, as the monsoon trough is well established, extending from north Bay of Bengal to west-northwesterly direction during these months.

\section{6b Region of occurrence of LPS causing very heavy rainfall}

The most favourable region of LPS is the NW Bay (figure 11) to cause very heavy rainfall over most parts of Orissa except some areas on eastern side of Eastern Ghat, northern upland and adjoining areas during all the months and the season as a whole, as most parts of Orissa lie in the southwest sector of LPS over the NW Bay. The NW Bay and WC
Bay are equally favourable regions of LPS for very heavy rainfall over eastern side of Eastern Ghat during all the monsoon months and the season as a whole. The eastern side of Eastern Ghat becomes windward side and hence gets intense rainfall with basic westerly monsoon flow changed over to easterly over the region in association with the LPS over WC Bay. Similarly, the NW Bay and GWB are most favourable regions of LPS to cause very heavy rainfall over some parts of northern upland and adjoining areas in different monsoon months, being most significantly so during June. It may be due to the fact that the northern upland and adjoining areas lie more close to but in the southwest sector of the LPS over GWB and the number of LPS days over GWB is maximum in June (figure 4). Orissa is also a most favourable region of LPS to cause very heavy rainfall over some areas of western Orissa, as this region lies in the southwest sector of LPS over Orissa.

The second category of most favourable regions is not shown in the figure. However, the stations getting very heavy rainfall with NW Bay as most 

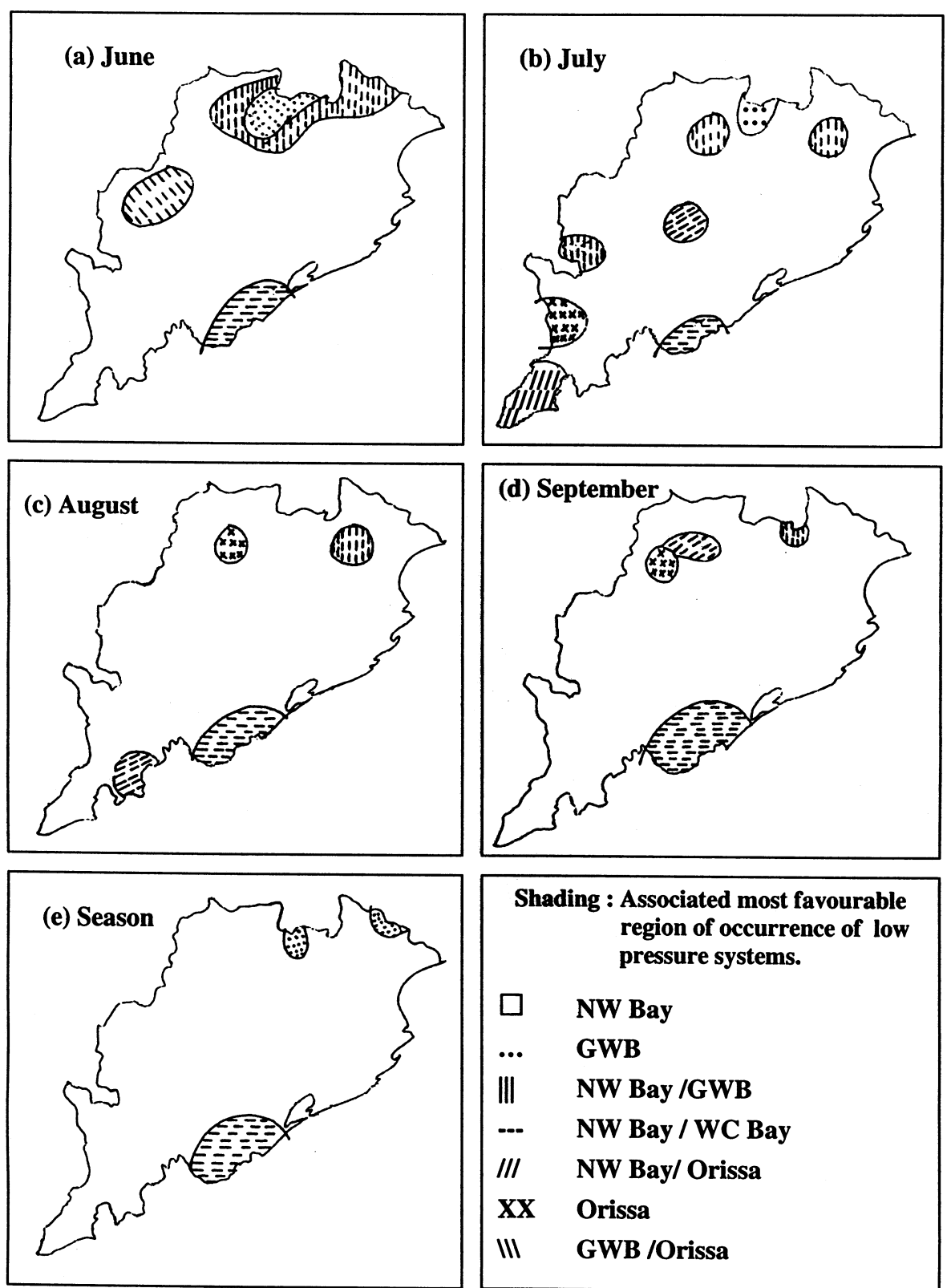

Shading : Associated most favourable region of occurrence of low pressure systems.



Figure 11. Regions of very heavy rainfall associated with most favourable region of occurrence of low pressure system causing very heavy rainfall over Orissa.

favourable region of LPS, has GWB/Orissa as the second category of most favourable region of LPS to get very heavy rainfall. Similarly, the stations getting very heavy rainfall with GWB/Orissa as most favourable region of LPS, has the NW Bay as the second category of most favourable region, station getting very heavy rainfall with NW Bay and GWB as equally most favourable region of LPS, has Orissa as the second category of most favourable region of LPS, station getting very heavy rainfall with NW Bay and Orissa as equally most favourable regions has GWB as the second category of most favourable region of LPS. The NW Bay and WC Bay are the only regions of LPS to cause very heavy rainfall over most of the stations on eastern side of Eastern Ghat.

The sum total of the percentage frequencies of LPS over first two categories of favourable regions out of total frequency of LPS over all the regions under consideration causing very heavy rainfall is $100 \%$ for very heavy rainfall over most parts of Orissa during July and September; over most parts of Orissa except many places on the eastern side of northern upland during June and over most parts of Orissa except some places on the western side of Eastern Ghat during August. The sum total of the percentage frequencies of LPS over first two categories of favourable regions is $100 \%$ during the 
season for very heavy rainfall over eastern side of Eastern Ghat. It is less for very heavy rainfall over some places in western part of Eastern Ghat and eastern side of northern upland. Over these regions, the very heavy rainfall may occur, though rare, due to interaction of orography with the basic monsoon flow and the LPS over the neighbouring regions like EMPC and JKD.

\section{6c Correlation between number of LPS days over different regions and frequency of very heavy rainfall over different stations in Orissa}

The spatial distribution of $\mathrm{CC}$ between the number of LPS days over different regions under consideration, as shown in figure 2(b) and the frequency of very heavy rainfall over different stations under consideration as shown in figure 2(a) is shown in figure 12. The increase in number of LPS days over NE Bay causes significant increase in frequency of very heavy rainfall at some places over southern part during June and over northeastern part of Orissa during August. During all the months and the season except September, the frequency of very heavy rainfall increases at a few places over south Orissa and north interior Orissa with increase in LPS days over the NW Bay. It increases at a few places over south coastal Orissa during September with increase in LPS days over the NW Bay. As the monsoon trough is less marked due to withdrawal phase of monsoon during September, activity is confined to south coastal Orissa only during September. The frequency of very heavy rainfall over south Orissa, specially over the eastern side of Eastern Ghat and adjoining areas of coastal plain significantly increases with increase in LPS days over WC Bay. It significantly decreases over some parts of interior Orissa during July and August.

The increase in number of LPS days over Orissa causes significant increase in frequency of very heavy rainfall over western side of Eastern Ghat and adjoining central river basin during all the months and the season except September as this region lies in the southwest sector of this LPS. With the increase in LPS days over EMPC, the frequency of very heavy rainfall increases over a few places in adjoining areas of southwest hilly region only during June and the LPS over EMPC has no significant impact in other months as most parts of Orissa lie in the rear sector of this LPS and the rear sector is the minimum convergence sector. The interaction of basic monsoon flow with the LPS over JKD and orography is sufficient enough to cause very heavy rainfall at some places over western side of Eastern Ghat and adjoining areas of central river basin during August and over some parts of western side of Eastern Ghat and northern upland during June. The increase in number of LPS days over GWB causes significant increase in frequency of very heavy rainfall at some parts over north Orissa during June and July and over north coastal Orissa during August, September and the season as a whole, as north Orissa lies in the southwest sector of the LPS over GWB. The increase in number of LPS days over BDS causes significant increase in frequency of very heavy rainfall at isolated places in northern upland and north coastal plain only as these areas lie in outermost part of the southwest sector of LPS over BDS. Thus the correlation analysis confirms the findings that the region lying in the southwest sector and windward sector with respect to the LPS gets very heavy rainfall as mentioned in previous para of the analysis.

\subsection{Trend in the frequency of very heavy rainfall over Orissa during recent years (1980-1999)}

The spatial distributions of linear trend coefficients in the frequencies of very heavy rainfall events over Orissa during 1980-1999 are shown in figure 13 . The trend coefficients are not statistically significantfor most parts of Orissa except some parts in northeast Orissa (MBJ district). It may be due to the fact that the number of LPS days shows no significant trend. According to Mooley and Shukla (1989), the number of LPS days over the Indian region does not show any significant trend during 1888-1983. The MBJ district shows significant increasing trend in frequency of very heavy rainfall in recent years. The western side of Eastern Ghat and adjoining areas as well as KNJ district show decreasing trends during all the months and the season. According to De (2001), the frequency of heavy rainfall $(\geq 65 \mathrm{~mm})$ during monsoon season shows increasing trend over some parts of the country. According to him, most parts of Orissa, specially the region extending from central part of coastal Orissa to northwest Orissa shows insignificant trend in frequency of heavy rainfall. While the northeast Orissa shows significant rising trend, western side of Eastern Ghat shows significant decreasing trend in frequency of heavy rainfall.

\section{Conclusions}

The following broad conclusions are drawn from the above results.

The frequency and intensity of very heavy rainfall are higher in July and August than in June and September. During July, August and season as a whole; there is a region of significantly higher frequency and intensity with less interannual 
(a) June

(b) July

(c) August

(d) September

(e) Season

(i)


(ii)

(iii)

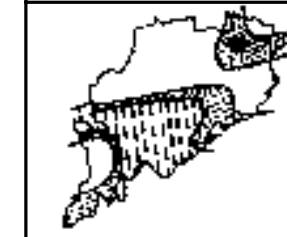

(iv)
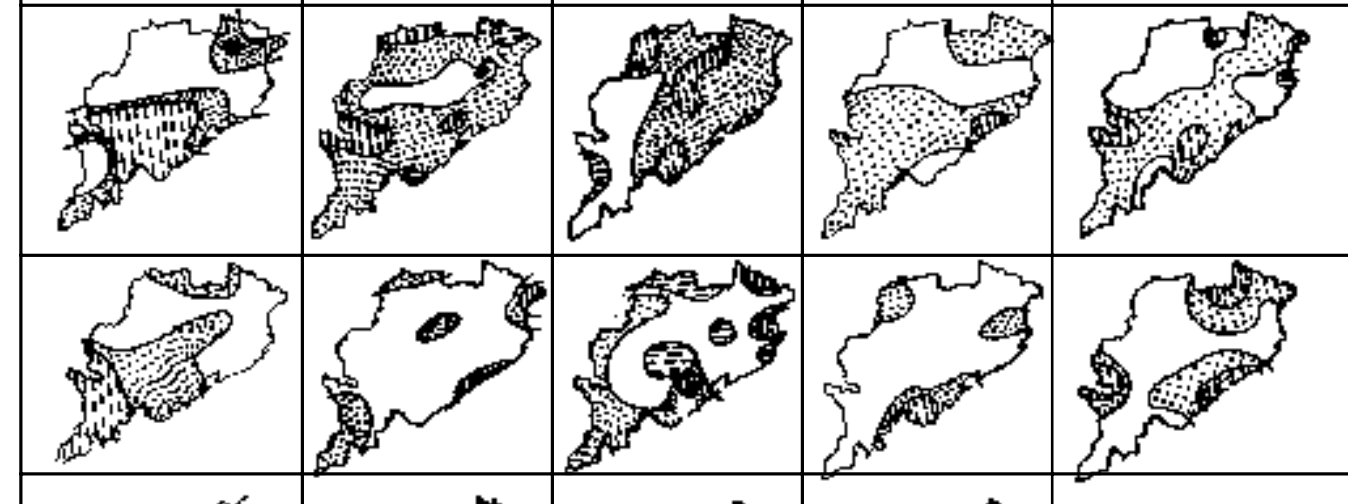

(v)

(vi)
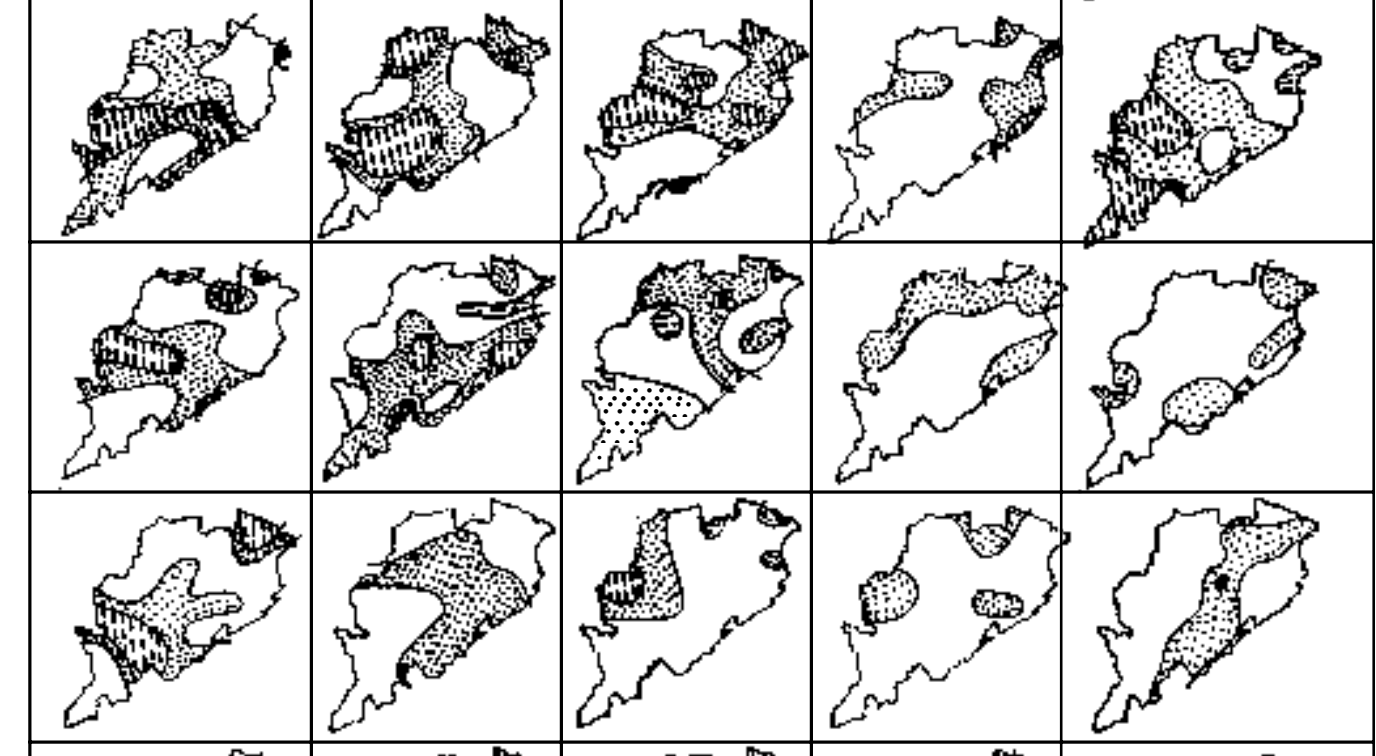

(vii)



Regions of LPS: (i) NE Bay (ii) NW Bay (iii) WC Bay (iv) Orissa (v) East MP \&

Chhatishgarh (vi) Jharkhanda (vii) GWB (viii) Bangladesh

... Positive CC ||| Positive CC Significant at $90 \%$ confidence level

$\square$ Negative $\mathrm{CC}==$ Negative CC Significant at $90 \%$ confidence level

Figure 12. Correlation coefficients between number of low pressure system (LPS) days over different regions as shown in figure 2(b) and frequency of very heavy rainfall over different stations in Orissa as shown in figure 2(a) during different monsoon months and the season as a whole. 

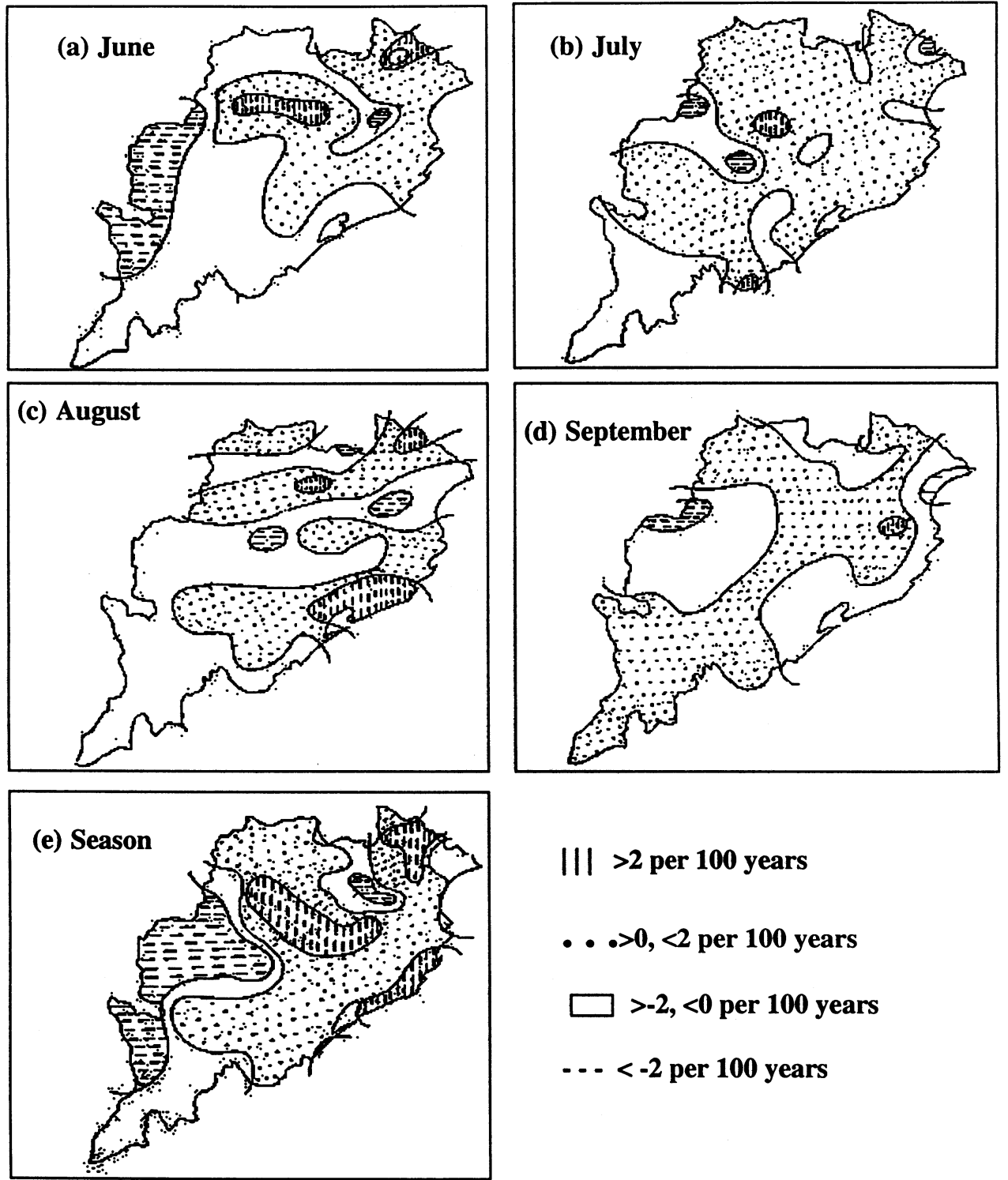

\section{III >2 per 100 years}

.. $>0,<2$ per 100 years

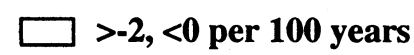

$\ldots-2$ per 100 years

Figure 13. Linear trend coefficients (days per 100 years) in the frequency of very heavy rainfall over Orissa during different monsoon months and the season.

variability in very heavy rainfall extending from central part of coastal Orissa in the southeast towards northwest Orissa.

The eastern part experiences less frequency with higher interannual variability of very heavy rainfall compared to the western and central parts of Eastern Ghat during all the months and the season except September. During September, unlike other months, there is a region of almost nil frequency of very heavy rainfall along the Eastern Ghat. Also the very heavy rainfall events over eastern side of Eastern Ghat are less intense than that over western and central part. Some parts of KNJ and adjoining areas experience less intense rainfall during all the monsoon months and the season as a whole.
The percentage frequency of very heavy rainfall caused by LPS out of total frequency of very heavy rainfall is maximum in September followed by June. It is higher over the eastern side than over the western side of Eastern Ghat during July, August and the season as a whole. The western part could get very heavy rainfall in association with small scale synoptic systems like cycir due to orographic enhancement of rainfall.

The most favourable region of LPS is NW Bay followed by GWB/Orissa to cause very heavy rainfall over most parts of Orissa except the eastern side of Eastern Ghat, northern upland and adjoining areas during all the months and the season. The NW Bay and WC Bay are equally most favourable regions of LPS for very heavy rainfall over eastern 
side of Eastern Ghat during all monsoon months and the season as a whole. The GWB and NW Bay are the favourable regions of LPS to cause very heavy rainfall over northern upland and adjoining areas.

The correlation analysis between number of LPS days over different regions and the frequency of very heavy rainfall over different stations in Orissa confirms that the region lying in the southwest sector and windward sector with respect to the LPS gets more very heavy rainfall.

The frequency of very heavy rainfall does not show any significant trend over Orissa except some places in northeast Orissa, which exhibits significant increasing trend in recent years.

\section{Acknowledgements}

The authors are thankful to India Meteorological Department for providing the data to carry out the work. The authors are also thankful to Sri A M Nayak, Meteorological Centre, Bhubaneswar and Sri Narendra Kumar, Centre for Atmospheric Sciences, IIT Delhi, New Delhi for typing the manuscript.

\section{References}

Banerjee S K 1929 The effect of the Indian mountain ranges on the configuration of the isobars; Ind. J. Phys. IV 477-502.

Browning K A 1980 Structure, mechanism and prediction of orograpically enhanced rain in Britain; GARP Publication series, No. 23, WMO 88-114.

Chand R and Gupta G R 1991 Heavy rain spell during January 1989 over northwest India; Mausam 42 301-304.

De U S 2001 Cimate change impact: Regional scenario; Mausam 52 201-212.

Desai D S, Thade N B and Huprikar M G 1996 Very heavy rainfall over Panjab, Himachal Pradesh and Haryana during 24-27 Sep. 1988 - Case study; Mausam 47 269-275.
Dhar O N and Mhaiskar P R 1973 Areal and point distribution of rainfall associated with depressions/storms on the day of crossing the east coast of India; Indian J. Met. Geophys. 24 271-278.

Dhar O N and Nandergi S 1993 Spatial distribution of severe rain storms over India \& their associated area rainfall depths; Mausam 44 373-380.

Dhar O N and Nandergi 1993(a) The zones of severe rainstorm activity over India, International J. Climatology 13 301-311.

Dubey D P and Balakrishnan T K 1992 A study of heavy to very heavy rainfall over MP for the period 1977 to 1987; Mausam 43 326-329.

Ganesan G S, Muthuchami A and Ponnuswamy A S 2001 Various classes of rainfall in the coastal stations of Tamilnadu; Mausam 52 433-436.

Kasahara A 1980 Influence of orography on the atmospheric general circulation; Garp Publication series, No. 23, WMO 1-49.

Krishnamurti T N , Mobinasi J and Pan H L 1976 Numerical simulation of the Somali jet; J. Atmos. Sci. 33 $2350-2362$.

Mooley D A and Shukla J 1989 Main features of the westward moving low pressure systems which form over the Indian region during the summer monsoon season and their relation to the monsoon rainfall; Mausam 40 137-152.

Pathan J M 1993 Latitudinal variation of rainfall during the month of July in relation to the axis of monsoon trough over India; Mausam 44 384-386.

Raghavan K 1973 Break monsoon over India; Mon. Wea. Rev. $10133-44$.

Rajamani S and Rao K V 1981 On the occurrence of rainfall over southwest sector of monsoon depression; Mausam 32 215-220.

Rakhecha P R and Pisharoty P R 1996 Heavy rainfall during monsoon season: point and spatial distribution; Current Science 71 179-186.

Rao C P and Rao P V R 1993 Influence of cyclonic disturbances from Sea on rainfall over Eastern Ghat in Andhra Predesh; Mausam 44 153-162.

Sarkar R P 1966 A dynamical model of orographic rainfall; Mon. Wea. Rev. $94555-572$.

Sarkar R P 1967 Some modifications in a dynamical model of orographic rainfall; Mon. Wea. Rev. 95 673-684.

Smith R B 1979 The influence of mountains on the atmosphere; Advances in Geophysics $\mathbf{2 1}$ $187-230$. 